\title{
Selvmordsfare og Internett: Hvordan gi beskyttelse?
}

Ved Henning Herrestad

\section{Denne artikkelen beskriver hva som har gitt opphav til bekymring for at Internett gir økt selvmordsfare, og hvordan publisering av selvmordsinformasjon via Internett betraktes fra en juridisk synsvinkel. Til slutt gis det eksempler på hvordan ulike organisasjoner har tatt Internett i bruk for å drive selvmordsforebygging.}

\section{Innledning}

I 2007 utgav Seksjon for selvmordsforskning og -forebygging (SSFF), i samarbeid med Kolofon forlag, boken Selvmordsfare og Internett: K an jussen gi beskyttelse?.

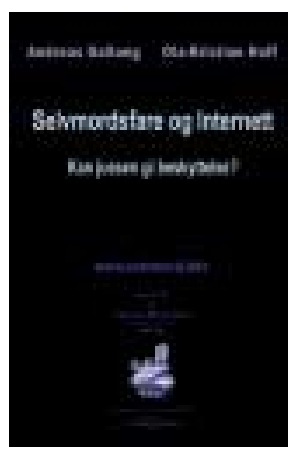

Boken ble skrevet på oppdrag for SSFF av advokatene A ndreas $G$ altung og Ola-Kristian $\mathrm{H}$ off ( $\mathrm{G}$ altung $\& \mathrm{H}$ off, 2007). Første del av denne artikkelen er basert på denne boken.

I artikkelens annen del er fokus på hvordan Internett kan være en ressurs i arbeidet med å drive selvmordsforebygging. H ovedfokuset er på norske initiativ. I tillegg omtal es initiativer fra Storbritannia, Irland og A ustralia som ble presentert på verdenskongressen til International A ssociation of Suicide Prevention (IA SP) i august 2007.

\section{Internett - en fare for} selvmordsnære?

Bekymringen for at Internett kan bidra til å øke sel vmordsfaren hos personer som allerede er selvmordsnære, har grunnlag i en rekke medieoppslag om hvordan selvmordsinformasjon spredd via Internett syneså ha spilt en rolle ved flere selvmord og selvmordsforsøk. For eksempel skriver den danske journalisten Kim Engel brechtsen:

"Disse Internet sider har allerede ført til flere selvmord i Danmark og andre lande. Jeg har selv haft problemet uhyggeligt tæt inde på livet. For tre år siden stod en sådan hjemmeside nemlig fremme på min søns computerskærm, da han val gte at tage sit eget liv en mørk nattetime - kun 16 år gammel. Siden viste, hvordan man hænger sig selv fra et dørhåndtag - og han havde desverre fulgt anvisningen til punkt og prikke." (Engelbrechtsen, 2005)
Engel brechtsens sønn fant altså informasjon om hvordan han kunne ta livet av seg på Internett. Tilsvarende informasjon finner man også i bøker, blader og aviser, på film og i sangtekster. Internett gjør slik informasjon mer tilgjengelig enn tidligere ved at hvem som helst kan finne den med noen få tastetrykk.

Keith Hawton og Kathryn W illiams (2005) står bak en systematisk kunnskapsoversikt om medias innflytelse på sel vmordsatferd. De fastslår at det ikke finnes forskning som viser hvilken rolle Internett spiller i forhold til selvmordsatferd, men i forhold til andre massemedier konkluderer de:

"There is clear evidence that media reporting and portrayal of suicidal behaviour can lead to increases in suicidal behaviour under certain circumstances. The potential impact of the media is more marked where methods of suicide are specified, there is prominent and/or repetitive news coverage, and where celebrity suicides are reported. Young people, in particular, appear to be more vulnerable to media effects." (H awton \& W illiams, 2005, s. 303) $M$ ye av det som publiseres i andre massemedier, havner i dag på Internett via medien es nettaviser. Det er grunn til å tro at $\mathrm{H}$ awton og W illiams konklusjoner gjelder uavhengig av hva slags medium informasjonen publiseresi, og derfor også for Internett.

Internett sies å ha demokratisert massemediene ved at alle får anledning til usensurert å publisere akkurat hva de vil enten vie egne nettsider, via diskusjonssider på nettet, via nettsamfunn som Facebook, eller via dagbøker på nett (blogger). De kan publisere både tekst, bilder og film. Det er mange enkeltpersoner og grupper som gir positive framstillinger av selvmordsatferd, enten fordi de selv er suicidale, eller fordi de tiltrekkes av det dramatiske og groteske.

Internett er ikke bare en publikasjonskanal, men en kommunikasjonskanal.
Internett og mobiltel efon smelter sammen ved at man kan finne fram på Internett på mobiltelefonen og poste meldinger, bilder og film fra mobiltel efonen på Internett. Det har vært en rekke medieoppslag om mennesker som har funnet støtte og hjelp til å gjennomføre sine selvmordsplaner via slik kommunikasjon på Internett. For eksempel var det i England i 2007 oppslag både om en person som chattet med sine venner i flere timer mens han tok sitt eget liv med en overdose medikamenter uten at noen av dem prøvde å hindre ham, og om en annen som egget av sine kamerater hang seg mens webkameraet kringkastet det hele på Internett (G ill, 2007). I N orge er avisoppslagene i 2001 , om den norske gutten som via Internett inngikk en selvmordspakt med en østerriksk jente om å hoppe fra Preikestolen i Rogaland, det mest kjente eksempelet (Knutsen, 2001).

Fra U SA er det eksempler på mennesker som bruker Internett til å komme i kontakt med mennesker de kan manipulere i retning selvmord. En såkalt "suicide predator" ble anholdt i 0 regon i 2005, og etterforskningen viste at han hadde forsøkt å få 31 enslige kvinner til å ta livet av seg på Valentindagen 14. februar (Booth, 2005). H an hadde holdt på med å lokke kvinner til å ta sitt eget liv de siste fem årene.

O m man leter på Internett etter sider med selvmordsinformasjon, er det lett å finne eksempler fra utlandet, men det er vanskelig å finne norske eksempler.

Er det ikke forbudt å publisere selvmordsinformasjon?

I 2005 ba tidsskriftet Suicidologi professor Jon Bing om å klargjøre hvorvidt det i N orge er forbudt å tilskynde noen til å ta sitt eget liv. Bing kom til at det var et "hull" i lovgivningen som gjør at selv om det er straffbart å oppfordre til lovbrudd, er det ikke straffbart å oppfordre til selvmord, i og med at selvmord ikke i seg selv er forbudt (Bing, 2005). 
Samme år ble J ustisdepartementet bedt om å uttale seg om norsk rett på dette punktet av danske justismyndigheter, og de uttalte at oppfordringer til selvmord var forbudt etter norsk lov (Straffelovrådet, 2005). SSFF fikk da advokatene A ndreas $\mathrm{G}$ altung og O la-K ristian $\mathrm{H}$ off til å utrede spørsmålet, og de kom fram til at det kun er det sist nevnte eksempelet på en "suicide predator" som vil kunne rammes av straffeloven § 236:

"§ 236: Den, som medvirker til, at nogen berøver sig selv Livet eller tilføyer sig betydelig Skade paa Legeme eller H elbred, straffes som for M edvirkning til Drab eller grov Legemsbeskadigelse, øvet mod en samtykkende. Straf kommer ikke til A nvendelse, naar $D ø d e n$ eller betydelig Skade paa Legeme eller H elbred ikke er Indtraadt."

Publisering av generelle oppfordringer og metodebeskrivelser, der det ikke er noen direkte kontakt mellom forfatteren og den som tar livet av seg, vil derimot ikke falle inn under de juridiske kravene for at noe er "medvirkning".

Justisdepartementet henviser i sin uttalelse også til straffeloven $\S 140$ (0 ppviglerparagrafen) som forbyr offentlige oppfordringer, tilskyndelser og forherligelse av straffbare handlinger. $\mathrm{N}$ å er ikke selvmord en straffbar handling, men $§ 140$ nevner også handlinger det er straffbart å forlede eller tilskynde til. For eksempel er prostitusjon tillatt, men det er forbudt å forlede til det.

Det finnes ingen rettspraksis der oppfordringer til selvmord eller forherligelse av selvmord er rammet av straffel oven $\S 140$. I følge $\mathrm{G}$ altung og H off er det lite sannsynlig at påtalemyndighetene vil ta ut tiltale mot et nettsted som inneholder selvmordsinformasjon på grunnlag av $\S 140$. En viktig grunn er at Norge har et sterkt vern om ytringsfriheten gjennom Grunnloven $\S 100$ og Den europeiske menneskerettighetskonvensjon artikkel 10. Riktignok åpner artikkel 10 for at stater kan begrense ytringsfriheten også for å beskytte offentlig trygghet og helse. $M$ en i N orge er ingen slik begrensning blitt vedtatt. En annen viktig grunn for påtalemyndigheten til å nøle med å ta ut tiltale, er strafferettens prinsipp om at det må være dekning for at den handlingen det er aktuelt å straffe er angitt i straffe- budets gjerningsbeskrivelse. Straffel oven ble til lenge før Internett fantes. Den er derfor ikke tiltenkt å ramme publisering av selvmordsinformasjon på Internett.

I verden for øvrig er det bare tre land som har forbud som kan ramme publisering av selvmordsinformasjon på Internett. I Portugal fikk de i 1995 en bestemmelse (art. 139) i straffeloven som sier at en person som på en eller annen måte promoterer eller averterer produkter gjenstander eller metoder for å fremkalle døden, for derved å oppfordre til selvmord, kan dømmes til fengsel i inntil 2 år eller bøter tilsvarende inntil 240 dagers fengsel (Straffel ovrådet, 2005). I Frankrike fikk de i 2002 en bestemmelse (art. 223.1315) i straffeloven om at tilskyndel se av andre personer til å gjøre selvmord straffes med inntil tre års fengsel eller med bøter opp til 45.000 euro når tilskyndel sen følges av et selvmord eller et forsøk på selvmord. I A ustralia fikk de i 2006 en bestemmel se (art. 474.29A -B og 474.30) i straffel oven som forbyr råd eller oppfordringer til selvmord og selvmordsforsøk. Ingen av disse landene har ennå noen rettspraksis med utgangspunkt i disse bestemmelsene.

$\mathrm{G}$ altung og $\mathrm{H}$ off vurderer en rekke bestemmelser norske myndigheter kan ta utgangspunkt i dersom man skulle kriminalisere tilskyndelser til selvmord. Et forhold som kompliserer rettsforfølgelse av informasjon på Internett som måtte være ulovlig, er at Internett er et globalt fenomen. N orske myndigheter vil kunne rettsforfølge de ansvarlige dersom de ansvarlige befinner seg i N orge og er norske borgere. Dersom informasjonen er publisert fra en utenlandsk server, er det langt vanskeligere å stoppe den, selv om de ansvarlige skulle bli dømt. Dersom nettsidene ligger $i$ et annet land og drives av utlendinger, har norske myndigheter som hovedregel ingen ting de skulle ha sagt. Enkelte andre land hevder i prinsippet jurisdiksjon uavhengig av sitt territorium, men i praksis vet myndighetene at det er fåfengt å rettsforføl ge personer de ikke kan få tak i. $0 \mathrm{~m}$ N orge fikk en ny strafferettsbestemmel se på linje med Portugal, Frankrike eller A ustralia, ville det neppe få noen stor praktisk betydning. Dersom noen ønsket å omgå et slikt forbud, vil de enkelt kunne inngå avtaler om å få legge ut informasjon på utenlandske servere.

\section{Stoppes ikke selvmords- informasjon av \\ Vær Varsom-plakaten?}

$\mathrm{N}$ år en avis har publisert reportasjer om selvmord der for eksempel metoden er detaljert beskrevet, kan man av og til lese at avisen er blitt dømt for brudd på Vær V arsom-plakatens artikkel 4.9 som lyder:

"4.9. V ær varsom ved omtale av selvmord og selvmordsforsøk. U nngå omtale som ikke er nødvendig for å oppfylle allmenne informasjonsbehov. U nngå beskrivelse av metode eller andre forhold som kan bidra til å utløse flere selvmordshandlinger."

V ær Varsom-plakaten er ikke norsk lov, men et presseetisk regelverk som er bindende for medlemmer av N orsk Presseforbund. Dersom medlemmene bryter disse reglene, kan de bli dømt av Pressens Faglige U tvalg, men det får ingen strafferettslige konsekvenser. Pressen driver med andre ord en selvsensur som er strengere enn lovens krav. D ette er eksempel på en form for selvregulering som skjer innen mange ulike bransjer. M en den er altså ikke bindende for andre enn bransjeorganisasjonens medlemmer. Til gjengjeld har presseorganisasjonene i de fleste vestlige land tilsvarende ordninger, og stadig flere har bestemmelser som tilsvarer art. 4.9 (P.E. Kokkvold, personlig meddel else, 8.10.07).

I prinsippet finnes det en parallell til Pressens Faglige U tval g hos bransjeorganisasjonen for Internettleveran dører, IKT$\mathrm{N}$ orge. $\mathrm{N}$ ettnemnda ble i sin tid opprettet som IT-bransjens etiske utvalg som et prøveprosjekt. N ettnemnda er aldri formelt nedlagt, men IT-bransjen har heller ikke videreført prosjektet. I dag er det derfor ikke noe organ man kan innklage nettsider til, med mindre nettsidene drivesav en mediebedrift som er tilsluttet N orsk Presseforbund.

EU har tatt initiativ til et samarbeid om Safer Internet A ction Plan. H er går EU inn for bruk av selvregulering som virkemiddel. Videre støtter EU opprettelsen av meldelinjer der brukerne kan rapportere forekomsten av ulovlig materiale, og de støtter informasjons- og opplysningsvirksomhet om sikker Internettbruk.

I N orge ivaretas opplysningsvirksomheten om sikker Internettbruk av Statens medietilsyn www.saftonline.no, mens 
kriminal politiet, Kripos, driver meldelinjen for ulovelig materiale www.tips.kripos.no/tips/tips.asp. I praksis er det kun bilder av seksuelle overgrep mot barn (såkalt "barneporno"), samt rasistiske ytringer, som kan anmeldes til Kripos, for meldetjen esten er begrenset til ytringer som er klart forbudt ved lov.

\section{Kan ikke selvmordsinformasjon} stoppes av filtre eller overvåking?

K ripos samarbeider også med Internettleverandørene om å stoppe distribusjon av bilder av seksuelle overgrep mot barn til norske Internettbrukere, gjennom det såkalte barneporno-filteret. D ette samarbeidet er eksplisitt avgrenset til bilder av seksuelle overgrep mot barn, og skal ikke utvides til annet uønsket informasjon. Det er derfor ikke mulig å bruke dette filteret til å stoppe selvmordsinformasjon. Et slikt filter er en form for sensur som ikke kan pålegges noen uten klare forbud som i tilfellet med barnepornografi. I prinsippet er det muligå tilby et filter som det er frivillig å bruke, og man kan tenke seg at foreldre installerer et slikt filter for å beskytte sine barn. M en i praksis har det vist seg vanskelig å lage gode filtre som filtrerer verken mer eller mindre enn det man ønsker å stoppe, og som man ikke lett kan omgå. $M$ an ønsker for eksempel ikke at filteret skal stoppe selvmordsforebyggende sider. M an ønsker heller ikke at filteret gir inntrykk av å stoppe alle farlige sider uten à gjøre det. Det er en krevende oppgave å holde et slikt filter oppdatert. Den som tilbyr et filter, får et stort ansvar for ikke å skape falsk trygghet. I 2005 tok en 17 år gammel jente i England sitt liv. H un hadde funnet fram til selvmordsinformasjon på nett etter å ha omgått filteret foreldrene hadde installert (W hitehouse, 2005).

$M$ ange "chatterom" og diskusjonsgrupper på Internett er overvåket av moderatorer, som kaster ut deltagere som bryter reglene i chatterommet eller sletter uønskede innlegg i diskusjonen. Det finnes programmer som varsler når brukerne skriver visse ord som for eksempel selvmord.

Det finnes programmer som vil registrere og loggføre all trafikk på en PC og varsle om spesielt angitt informasjon. Foreldre som er bekymret for hva barna gjør på Internett, kan installere slike programmer. Det advares mot å gjøre dette fordi

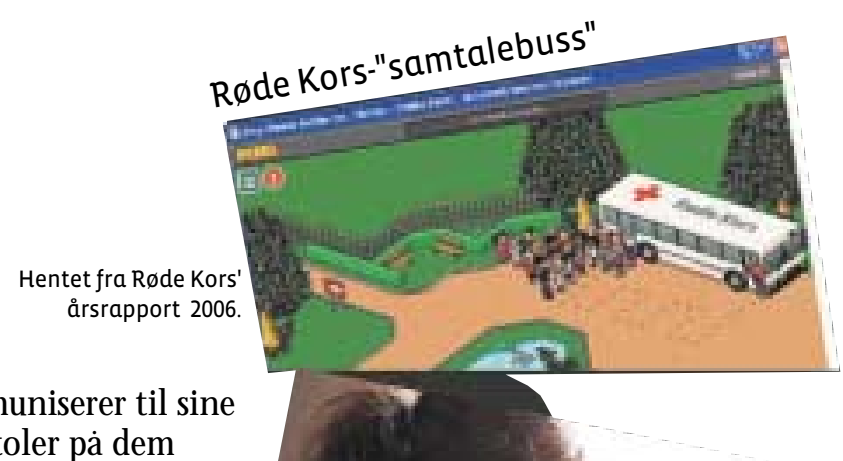

foreldre da kommuniserer til sin
barn at de ikke stoler på dem (Bjørkeng, 2008). Dersom institusjoner installerer noe slikt for å overvåke for eksempel pasienter, reises en rekke spørsmål i forhold til personvern, helsevern og institusjonens ansvar.

Teknisk sett kunne man laget slike former for overvåkning av kommunikasjonen på Internett. M en igjen er det en stor forskjell på å ha et frivillig tilbud om å delta i et overvåket "rom" og å gjøre overvåkning pålagt. En generell pålagt overvåkning av kommunikasjon på Internett er like uforenlig med ytringsfriheten som generell brevsensur eller telefonavlytting.

\section{Hvordan brukes Internett til å forebygge selvmord?}

På nettstedet www.selvmord.no har SSFF bygget opp en omfattende samling informasjon rettet mot fagfolk som arbeider med sel vmordsforebygging. Dette nettstedet har også viktig selvmordsforebyggende informasjon rettet mot mennesker i krise, både sel vmordsnære og pårørende. Internett gir også muligheter for direkte intervensjon overfor selvmordsnære personer. I 1994 startet The Samaritans en e-posttjeneste der frivillige hjel pere svarer på e-post fra hel e verden, www.samaritans/ org. I 2007 hadde de besvart over en million e-postmeldinger siden starten (A nthony Langan, personlig meddelelse, 28.8.07). N å kan man sende både e-post og tekstmel dinger fra mobiltelefon. The Samaritans åpnet derfor i 2005 en tjeneste hvor de svarer på tekstmeldinger.

I N orge begynte Kirkens SO S å utvikle en e-posttjeneste lik den til Samaritans i 1998. Fra 2003 har de hatt et krisetilbud på Internett med tjenesten SOS-meldinger som man finner på www.kirkenssos.no. M eldinger besvares av frivillige i Kirkens SO S innen 24 timer (H errestad, 2004). M ental $\mathrm{H}$ else har etablert en tilsvaren de tjeneste kalt Si det med ord: www.sidetmedord.no. Røde Kors har etablert et tilbud rettet mot barn og unge kalt K ors på halsen: www.korspahal sen.no.

$E n$ av de store utfordringene med å drive selvmordsforebyggende arbeid på Internett, er å være synlige for dem som trenger hjelpen.
Internett ligner

litt på flittig brukte plakatvegger der nye tilbydere hele tiden klistrer sine plakater over dem som alt henger på veggen. $M$ an vil gjerne at ens egne plakater skal være synlige foran de andre, og man vil gjerne være synlig på de veggene man tror blir sett av dem man vil nå. Søketjenester som K vasir er basert på at dem som betaler mest blir plassert øverst, mens G oogle ganske konsekvent viser de sidene øverst som flest mennesker har klikket seg inn på ved tidligere søk. T he Samaritans har inngått avtaler med $\mathrm{G}$ oogle om at deres hjelpetilbud skal komme opp på første side med søkeresultater når mennesker søker på selvmordsrelaterte ord (A nthony Langan, personlig kommunikasjon 28.8.07). The Samaritans har også et samarbeid med tilretteleggerne av mange populære diskusjonsgrupper og chatlinjer slik at deltagere som forteller om selvmordstanker, blir informert om muligheten for å kontakte The Samaritans. Det skjer enten ved at moderatoren sender dem en melding, eller ved at ord som selvmord utløser en mel ding ( såkalte autoresponders).

En type Internett-tjenester som er blitt veldig populære de siste årene, er såkal te nettsamfunn. N ettsamfunn som Facebook har i N orge tusenvis av deltagere, og mange bruker flere timer daglig på å holde kontakt med venner og kjente i nettsamfunnet. En måte å være synlig på er å gjøre seg synlig i slike nettsamfunn. Røde Kors startet for eksempel i 2006 et prøveprosjekt der de inviterte barn og unge til gruppesamtaler ledet av voksne til faste tider hver uke ( $\mathrm{N}$ ordby et al., 2007). På møtestedet www.habbohotell.no blir barna invitert inn i en Røde Kors"samtal ebuss". 
I Storbritannia og I rland har nettsamfunnet bebo.com blitt svært populært. Bebo ønsker å hjelpe sine brukere og har opprettet sidene bebo.com/B eW ell for å formidle kontakt med hjel petilbud. Bebo har også drevet forebyggen de informasjonsarbeid gjennom å lage fiktive personprofiler der ungdommer tilsynelatende står fram og forteller om vanskeligheter de har hatt, og om hva som hjalp dem til å komme ut av vanskelighetene. Slike profiler inviterer andre ungdommer til å gi sin respons på fortellingen, og flere slike fortellinger har, iføl ge Bebos an satte Rachel 0 . C onnell, fătt overveldende respons (Rachel 0 . Connell, personlig meddelelse 28.8.07). H un mener at andre unge lærer hvor de kan få hjelp og hvordan de bedre kan takle sine psykiske vanskeligheter gjennom å lese om hva skikkelser de kan identifisere seg med har gjort.

En annen type Internett-tilbud som er svært populært, er online dataspill. D et kan enten være spill man spiller alene, eller mot andre spillere rundt i verden. Slike spill kan også brukes i forebyggende virksomhet. Basert på forskning om sosial kognisjon, har selskapet M indH abits www.mindhabits.com utviklet dataspill som ved gjentatt bruk påvirker brukerens oppmerksomhet, sik at brukeren blir mindre oppmerksom på sosial informasjon som skaper en stressrespons. $M$ an har for eksempel påvist i kontrollerte eksperimenter at personer som gjentatte ganger plukker ut bilder av smilende fjes $i$ en masse av sinte fjes, etterpå føler mindre stress før eksamen eller fungerer bedre som telefonselgere ( $D$ andeneau et al., 2007). Slike spill er utgangspunktet for Kirkens SO S' nettsider www.tafem.no. Sidene er utviklet i erkjennelsen av at tjenesten SOSmeldinger nesten utelukkende appellerer til unge jenter. $\mathrm{H}$ åpet er at disse mer spillorienterte sidene vil appellere til gutter. I følge Kirkens SOS i N orge har TaFemsidene vært brukt over 15000 ganger siden lanseringen i desember 2007 (K åre D ag $M$ angersnes, personlig meddelelse,

29.1.08).

I A ustralia driver stiftelsen Inspire målrettet forebyggende psykisk helsearbeid for ungdom: www.inspire.org.au. De har utviklet et avansert dataspill kalt Reach
0 ut $C$ entral: www.reachout.com.au som bygger på prinsipper fra kognitiv atferdsterapi. Dataspillet lar spillerne utforske hvordan tanker, følelser og atferd virker inn på deres psykiske helse. $M$ ålet er å gi ungdom anledning til å utvikle "life skills and resilience", dvs. ferdigheter til å leve og motstandskraft mot psykiske lidelser.

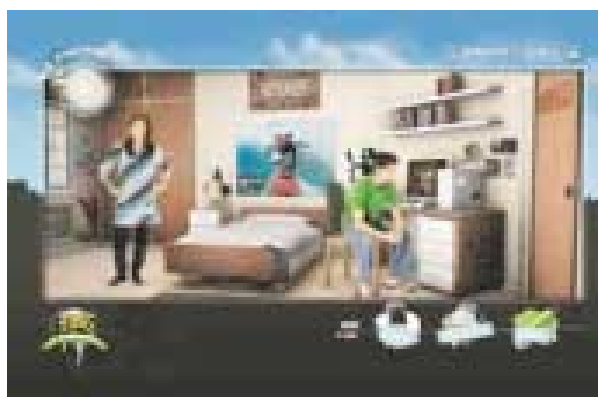

Fra Reach Out Central: www.inspire.org.au/what-we-doreach-out-reach-out-central-roc.html

\section{Avslutning}

Det kommer stadig nye medieoppslag om hvordan Internett har spilt en rolle i forbindelse med menneskers selvmord, og det uttrykkes bekymring og ønsker om å stoppe informasjon som kan være farlig for mennesker med selvmordstanker (jfr. Cyrillus, 2007). Juridisk sett er det vanskelig å pålegge noen sensur eller få noen dømt for å ha publisert informasjon om selvmord. Det er lite tenkelig at vi făr noen innstramninger av straffeloven med mindre forskning kan påvise at vi står overfor en alvorlig trussel mot offentlig trygghet og helse. Det finnes ingen slik forskning, og det er antagelig en stor utfordring å gjøre god forskning på dette området.

- Det er vanskelig å beskytte mennesker mot informasjon på Internett. Det er også mulig å forebygge selvmord gjennom å tilby dem forebyggende informasjon og ulike tjenester. På dette området skjer det mye positivt både i $\mathrm{N}$ orge og $\mathrm{i}$ utlandet. En Internett-tjeneste kan tiltrekke seg tusener av brukere, for så å forsvinne. Det dukker stadig opp nye tekniske muligheter. For den som ønsker å etablere nye forebyggende tjen ester på Internett, er det en stor utfordring at utviklingen skjer så raskt.

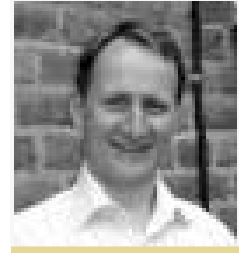

\section{$H$ enning $H$ errestad} er dr.philos. og nestleder for Seksjon for selvmordsforskning og -forebygging.

\section{Referanser}

Bing, Jon. (2005). Forbud mot tilskyndelse til selvdrap. (Elektronisk versjon). Suicidologi, 10, 2, 19.

Bjørkeng, P. K. (2008, 21. januar). Totalovervåker barna, http://forbruker.no/digital/nyheter/data/ article2207777.ece. A ftenposten.

Booth, J. (2005, 14. februar). St Valentine's day mass suicide pact fears. Times $\mathrm{O}$ nline. $\mathrm{H}$ entet 7.1.2007 fra http://www.timesonline.co.uk/tol/news/ world/article514400.ece

Cyrillus, Leif (2007, 29. november). U ngdomar lockas till självmord på Internet. (Elektronisk versjon). D agen.

Dandeneau, S. D., Baldwin, M. W., Baccus, J. R ., Sakellaropoul o, M., \& Pruessner, J. C. (2007).

C utting Stress $0 \mathrm{ff}$ at the Pass: R educing Vigilance and $R$ esponsiveness to Social T hreat by $M$ anipulating A ttention. Journal of Personality and Social Psychology, 93, 651-666.

Engelbrechtsen, K. (2005). Forbyd selvmordshjemmesiderne. (Elektronisk versjon). Suicidologi, $10,2,18$.

Galtung, A .\& H off, O. K. (2007). Selvmordsfare og Internett: $K$ an jussen gi beskyttelse? 0 slo: SSFF \& Kolofon forlag.

Gill, Victoria. (2007, M ay 6). Suicide surfers. The Sunday Times M agazine, 24-33.

H awton, K. \& Williams, K. (2005). Media influences on suicidal behaviour: evidence and prevention. I K.H awton (red.), Prevention and treatment of suicidal behaviour (s. 293-306). 0 xford: 0 xford U niversity Press.

H errestad, H . (2004). SO S-meldinger: Kirkens SO S' Internett-tjeneste for mennesker med selvmordstanker. Suicidologi, 9, 3, 23-26.

Knutsen, T. (2000). Selvmord, Internett og media. Suicidologi, 5, 3, 18-19.

N ordby, T. G ., H aaland, E. M ., \& Tørnby, L. (2007). R øde Kors-telefonens dialogtilbud for barn og ungdom, Â rsrapport 2006 R øde K ors.

Straffelovrådet. (2005). K riminalisering af generelle opfordringer til selvmord m.v. www.jm.dk/ imageblob/image. asp?objno=73898 (Rep. N 0 . 1462). København: Justitsministeriet Danmark.

Whitehouse, Paul. (2005, September 5). Suicide sites girl 'secretly got rid of parental controls' to access Internet. (Elektronisk versjon). Yorkshire Post. 